\title{
Conformational Manifold of Cryptand $K$ 2.2.2.BB and Its Complex with Potassium Ion
}

\author{
M. A. Krestyaninov, ${ }^{a}$ M. M. Kiseleva, ${ }^{\mathrm{b}}$ N. A. Gomzina, ${ }^{\mathrm{c}}$ and M. G. Kiseleva \\ ${ }^{\mathrm{a}}$ G.A. Krestov Institute of Solution Chemistry of the Russian Academy of Sciences, 153045 Ivanovo, Russian Federation \\ ${ }^{\mathrm{b}}$ St. Petersburg State University, Chemistry Institute, 198504 St. Petersburg, Russian Federation \\ ${ }^{\mathrm{c}}$ N.P. Bekhtereva Institute of Human Brain of the Russian Academy of Sciences, 197376 St. Petersburg, Russian Federation \\ ${ }^{\circledR}$ Corresponding authorE-mail: mgk@isc-ras.ru
}

\begin{abstract}
Conformations of cryptand $K$ 2.2.2BB and its complexes with potassium ion have been studied in this work by the density functional method. It is shown that along with the conformation of minimum energy there are several other stable conformations for both cryptand and its cation complex, with the potassium ion displaced to the periphery of the cavity in the latter case. The reason for this redistribution is the interaction with $\pi$-systems of benzene rings. The solvent effect on the conformer populations has been studied in the CPCM approximation. Cryptand complex conformer solvation selectivity has been found, which results in the dominance of one conformer with the minimum energy.
\end{abstract}

Keywords: Cryptand K 2.2.2BB, conformational manifold, solvent.

\section{Конформационное многообразие криптанда К 2.2.2.BB}

\author{
М. А. Крестьянинов ${ }_{1}^{\text {a }}$ М. М. Киселева, ${ }^{\text {b }}$ Н. А. Гомзина, ${ }^{\text {c }}$ М. Г Киселев ${ }^{\mathrm{a}}$

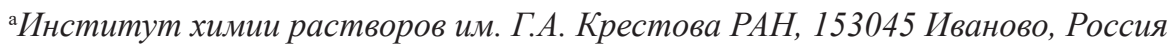 \\ ${ }^{\mathrm{b}}$ Санкт-Петербургский государственный университет, Институт химии, 198504 Санкт-Петербург, Россия \\ ${ }^{\mathrm{c}}$ ФББУН Институт мозга человека им. Н.П. Бехтеревой РАН, 197376 Санкт-Петербург, Россия \\ ${ }^{\circledR}$ E-mail: mgk@isc-ras.ru
}

\begin{abstract}
В работе методом функционала плотности исследованы конформации криптанда К 2.2.2BВ и его комплексов с ионом калия. Показано, что наряду с конформаџией, имеющей минимальную энергию, появляются несколько других устойчивых конформащий как для криптанда, так и его комплекса с катионом, причем в последнем случае существует устойчивая конфигурация, в которой ион калия смещеен к периферии полости. Причиной такого перераспределения является взаимодействие с $\pi$-системами бензольньх колец. Влияние растворителя на популяции конформации изучено в приближении СРСМ. Обнаружена селективная сольватация конформаций комплекса криптанда, что приводит к доминированию популяции одной конформации, имеющей минимальную энергию.
\end{abstract}

Ключевые слова: Криптанд К 2.2.2ВВ, конформационное многообразие, растворитель. 


\section{Introduction}

Positron emission tomography (PET) is the most sensitive method of medicinal visualization that makes it possible to quantify parameters of many physiological and biochemical processes in the living organism (perfusion, metabolism, receptor and neurotransmitter interactions) and thereby provides early and accurate diagnostics of oncological, cardiological, neurological and psychiatric diseases. ${ }^{[1-3]}$ The unique opportunities of PET are based on using short-living positron decay radionuclides: ${ }^{15} \mathrm{O},{ }^{13} \mathrm{~N},{ }^{11} \mathrm{C},{ }^{18} \mathrm{~F}$ as a label. The fluorine isotope ${ }^{18} \mathrm{~F}\left(\mathrm{~T}_{1 / 2}=110 \mathrm{~min}\right)$ is the most widely used radionuclide for production of labeled biomolecules or PET radiotracers due to its advantageous nuclear physical properties. The use of ${ }^{18} \mathrm{~F}$ as a radiotracer provides a high spatial resolution of the PET image due to low energy of the positrons $\left(\beta^{+}, 0.635 \mathrm{MeV}\right)$ and their small range in tissue before annihilation with an electron $(\sim 2.4 \mathrm{~mm})$. The relatively long half-life of ${ }^{18} \mathrm{~F}$ allows multi-step syntheses of different ${ }^{18} \mathrm{~F}$ labelled radiotracers and subsequent biodistribution patient studies. $\left[{ }^{18} \mathrm{~F}\right]$ in the chemical form of $\left[{ }^{18} \mathrm{~F}\right]$ fluoride ion is commonly produced via ${ }^{18} \mathrm{O}(p, n){ }^{18} \mathrm{~F}$ nuclear reaction by proton irradiation of ${ }^{18} \mathrm{O}$-enriched water target in medical cyclotrons with high radioactivity (up to $20 \mathrm{Ci}$ ). That is why nucleophilic radiofluorination becomes the main way of $\left[{ }^{18} \mathrm{~F}\right]$ fluoride introduction into biomolecules.

Aqueous fluoride is, however, inert as a nucleophile in substitution reactions due to its hydration. Therefore, these reactions are carried out in polar aprotic solvents (DMF, DMSO, acetonitrile) where $\left[{ }^{18} \mathrm{~F}\right]$ fluoride is transferred from water with the assistance of a phase transfer catalyst (PTC). The most common PTC in radiofluorination reactions is cryptand $\mathrm{K} 2.2 .2$ (4,7,13,16,21,24-hexaoxa-1,10-diazobicyclo[8.8.8]-hexacosane or kryptofix 2.2.2) forming stable coordination compounds with alkali metal cations, where the metal ion is surrounded by ligand atoms and isolated from the solvent molecules and counterion (usually carbonate). When water is removed, the complex of alkali metal cryptate with $\left[{ }^{18} \mathrm{~F}\right] \mathrm{flu}-$ oride becomes an extremely reactive nucleophilic agent. In 1986 it was first suggested to use kryptofix 2.2.2 for preparing fluorinating agent $\left[\mathrm{K}^{+} / \mathrm{K} 2.2 .2\right]\left[{ }^{18} \mathrm{~F}^{-}\right]$in the synthesis of $2-\left[{ }^{18} \mathrm{~F}\right]$ fluoro-2-deoxy-D-glucose, a well-known radiotracer of glucose metabolism. ${ }^{[4]}$ Since then K 2.2 .2 has been widely used for production of fluorinated radiopharmaceuticals that belong to different chemical classes. ${ }^{[3,5]}$ Researchers interest is mainly attracted by the kryptofix conformations lability: there are a few works that study conformational variety of $\mathrm{K}$ 2.2.2 and its complexes with metals and complexes of its derivatives with metals. ${ }^{[6-9]}$ The difference between $\mathrm{K} 2.2 .2$ and cryptand K 2.2.2BB (5,6,14,15-dibenzo-4,7,13,16,21,24hexaoxa-1,10-diazobicyclo [8.8.8]-hexacosane) is that the latter has two benzene rings. As reported, the radiofluorination efficiency with use of this ligand may be compared with the same with $\mathrm{K} 2.2 .2 .{ }^{[10]}$ Cryptand $\mathrm{K}$ 2.2.2BB is less toxic, has a lower detection limit by chromatography (determined by chromatography), can be easily removed by solid phase extraction with single-use cartridges, and could compete with $\mathrm{K}$ 2.2.2 as a PTC in nucleophilic fluorination.

In the 1980-90-s there were a few attempts to evaluate the effect of benzene rings on the size of $\mathrm{K} 2.2 .2 \mathrm{BB}$ cavity ${ }^{[11]}$ and on the stabilization of [K 2.2.2BB-metal] complex. ${ }^{[12]}$ But there have been no systematic studies of conformational distribution for this ligand. The main aim of this paper is to study conformational population of $\mathrm{K}$ 2.2.2BB, [K 2.2.2BB$\mathrm{K}^{+}$] complex, and to estimate the free energy and the enthalpy of $\mathrm{K}^{+}$binding with the cryptand in different polar solvents.

\section{Experimental}

Quantum chemical calculations were made in the Gaussian $09^{[13]}$ software package using the approximation of the density functional method. B3LYP functional was applied with the basis set $6-31++G(d, p)$. As is shown in ${ }^{[6]}$, the free energy of binding calculated in this approximation for the cryptand K 2.2.2 is in good agreement with the experimental results. All the calculated structures have no imaginary frequencies and thus correspond to energy minima. The energies of all the conformers were calculated with an account of zero vibrations $\left(E^{0}\right)$, the relative values of energy and free energy $\left(\Delta E^{0}, \Delta G\right)$ were calculated in respect to the most stable conformer. The energies and free energies of complex formation as well as the binding energy of cryptand with potassium ion were calculated from the corresponding conformer and cation.

The energy of intermolecular interactions of the studied complexes with account of superposition error (BSSE) was calculated by the following relation:

$$
\Delta E=E(\mathrm{AB}, \mathrm{aUb}, \mathrm{R})-[E(\mathrm{~A}, \mathrm{aUb}, \mathrm{R})+E(\mathrm{~B}, \mathrm{aUb}, \mathrm{R})] .
$$

The superposition error itself was determined by the following equation:

$$
\begin{aligned}
\mathrm{BSSE}=[E(\mathrm{~A}, \mathrm{aUb}, \mathrm{R})-E(\mathrm{~A}, \mathrm{a}, \mathrm{R})]+ \\
+[E(\mathrm{~B}, \mathrm{aUb}, \mathrm{R})-E(\mathrm{~B}, \mathrm{~b}, \mathrm{R})],
\end{aligned}
$$

where $\mathrm{E}(\mathrm{AB} ; \mathrm{aUb} ; \mathrm{R}), \mathrm{E}(\mathrm{A} ; \mathrm{a} ; \mathrm{R}), \mathrm{E}(\mathrm{B} ; \mathrm{b} ; \mathrm{R})$ are the energies of complex and initial molecules, respectively. Molecules A and $\mathrm{B}$ are separated by distance $\mathrm{R}$ in $\mathrm{AB}$ complex; $\mathrm{a}$ and $\mathrm{b}$ are the basis sets of separated molecules, $\mathrm{Ub}$ is the basis set of complex $\mathrm{AB}$.

Coordination bond stabilization energies $\left(E_{\mathrm{STAB}}\right)$ were calculated as part of NBO analysis (Natural Bond Orbital Analysis): ${ }^{[14]}$

$$
E_{\mathrm{STAB}}=-2 \mathrm{~F}_{\mathrm{IJ}}^{2} / \Delta E,
$$

where $\quad \mathrm{F}_{\mathrm{IJ}}=\left\langle\mathrm{n}|\mathrm{F}| \sigma^{*}>\right.$,

$$
\Delta E=<\sigma^{*}|\mathrm{~F}| \sigma^{*}>-<\mathrm{n}|\mathrm{F}| \mathrm{n}>\text {, }
$$

$\mathrm{n}, \sigma^{*}$ are the orbital of the electron lone pair and the antibonding orbital of the electron pair acceptor, $\mathrm{F}_{\mathrm{IJ}}$ is the nondiagonal element of the orbital Hamiltonian (F) describing the interaction (overlap) of these orbitals; $\Delta E$ is the difference of the orbital energies.

\section{Results and Discussion}

The number of possible dihedral angles around various bonds in $\mathrm{K} 2.2 .2 \mathrm{BB}$ is equal to 25 , therefore, the conformer set is very large $(\sim 103)$. Thus, the construction of full conformational manifold is practically impossible. Therefore, we selected two conformers with an open cavity, allowing the metal cation to freely migrate to the electron donor centers and three conformers with a closed cavity (Figure 1).

The cavity of conformers $\mathbf{1}, \mathbf{3}$ and $\mathbf{4}$ is partly closed by $\mathrm{CH}_{2}$-groups. Conformer $\mathbf{2}$ has the maximal open cavity, while the cavity of conformer $\mathbf{5}$ is completely blocked by the 
chain. Conformer 4 has the minimal energy (Table 1). The energies of conformers 1-3 differ from that of conformer 4 by not more than $10 \mathrm{~kJ} / \mathrm{mol}$, which is in the limit of thermal fluctuations. It means that the populations of these conformers are rather numerous. The energy of conformer $\mathbf{5}$ is higher than that of all the others and, therefore, its population is negligible.

The conformers obtained (Figure 1) were assumed as initial approximation for the structural optimization of their complexes with potassium ions. Complex formation is determined by both interaction with electron-donor centers and ligand structure alteration. Oxygen and nitrogen atoms with electron lone pairs act as cryptand electron-donor centers.

Depending on the direction of potassium attack, some conformers (4 and 5) formed two different complexes each, which allowed us to detect seven complexes. Most of the resulting structures formed rather strong interactions between potassium and oxygen or nitrogen atoms, which can be seen by the interaction energies and distances between potassium and electron pair donor atoms (Table 2).

The highest free energy of complex formation was found in complexes with conformers $\mathbf{2}$ and $\mathbf{4}$, with the structure of conformer 4 undergoing rather drastic changes, resulting in the formation of cation bonds with all the electron-donor centers of $\mathrm{K}$ 2.2.2BB (Figure 2).

As one can expect, complex 4-1 has the maximum binding energy, while the free energy of complex formation is higher in the complex formed from conformer $\mathbf{2}$ (Table 2). The reason for the cryptand structural changes can be understood by the NBO analysis. The stabilization energies
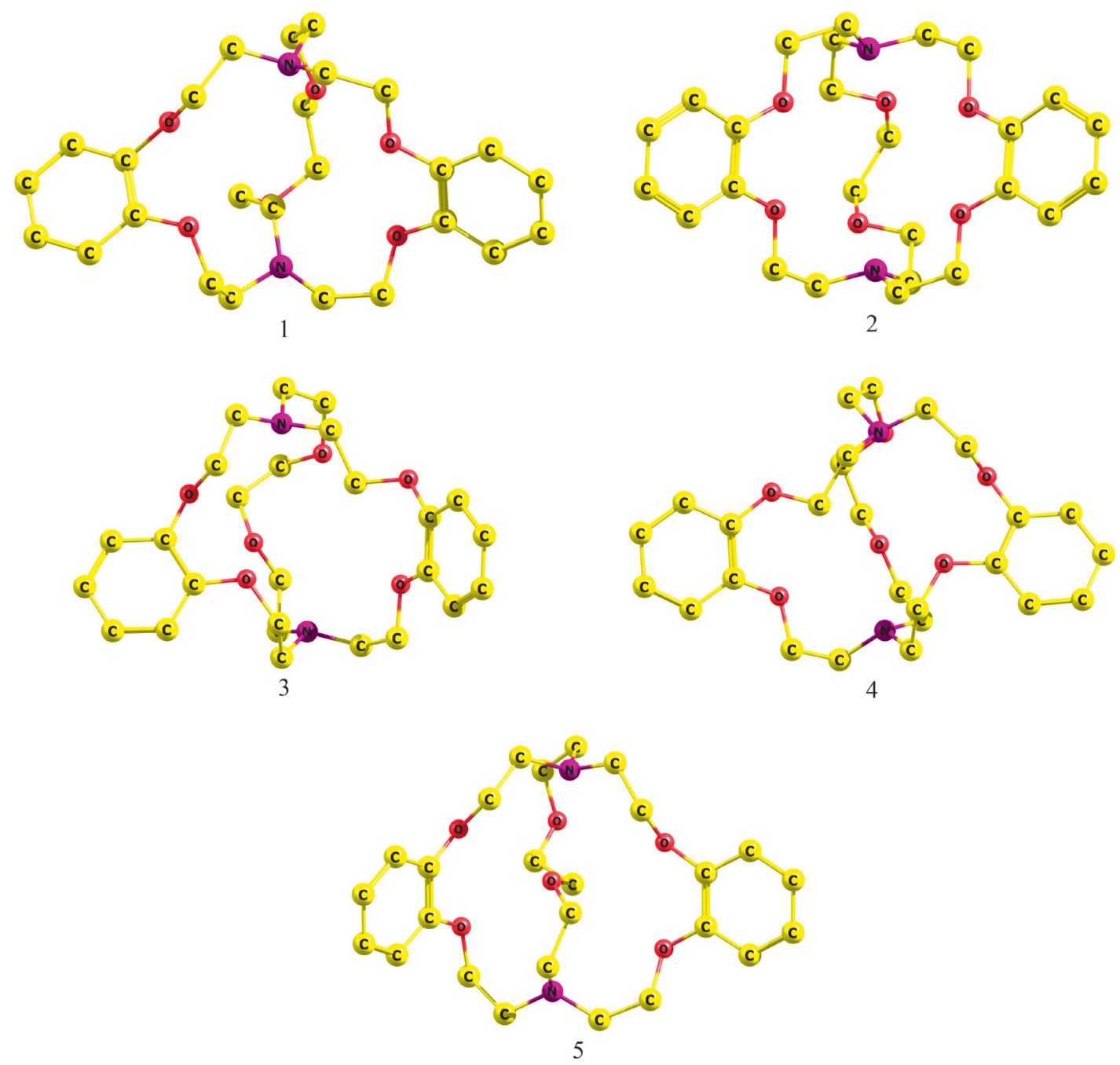

Figure 1. Structure of K 2.2.2BB conformers (hydrogen atoms are not shown).

Table 1. Electronic energies $\left(E^{0}\right)$, relative electronic energies $\left(\Delta A^{0}\right)$ and relative free energies $(\Delta G)$ of $\mathrm{K}$ 2.2.2BB conformers.

\begin{tabular}{cccccc}
\hline & $\mathbf{1}$ & $\mathbf{2}$ & $\mathbf{3}$ & $\mathbf{4}$ & $\mathbf{5}$ \\
\hline$-E^{0}$, a.e. & 1572.664764 & 1572.666599 & 1572.665344 & 1572.668129 & 1572.612663 \\
$\Delta A^{0}, \mathrm{~kJ} / \mathrm{mol}$ & 8.83 & 4.02 & 7.31 & 0.00 & 145.63 \\
$\Delta G, \mathrm{~kJ} / \mathrm{mol}$ & 9.27 & 5.96 & 8.18 & 0.00 & 155.88 \\
\hline
\end{tabular}


M. G. Kiselev et al.

Table 2. Energies $\left(\Delta E^{0}\right)$, free energies $(\Delta G)$ of complex formation and binding energy of $\mathrm{K} 2.2 .2 \mathrm{BB}$ conformers with $\mathrm{K}^{+}$ion, and distances $\mathrm{K}^{+}$-atom $(\mathrm{O}, \mathrm{N})$.

\begin{tabular}{cccccccc}
\hline & $\mathbf{1}$ & $\mathbf{2}$ & $\mathbf{3}$ & $\mathbf{4}$ & $\mathbf{4 - 1}$ & $\mathbf{5}$ & $\mathbf{5 - 1}$ \\
\hline$\Delta E^{0}, \mathrm{~kJ} / \mathrm{mol}$ & -223.72 & -297.76 & -149.91 & -129.20 & -296.80 & -85.36 & -163.02 \\
$\Delta G, \mathrm{~kJ} / \mathrm{mol}$ & -187.02 & -295.50 & -112.79 & -94.18 & -258.90 & -54.44 & -128.30 \\
$E_{\text {int }} \mathrm{kJ} / \mathrm{mol}$ & -256.44 & -326.56 & -184.35 & -169.58 & -340.83 & -91.17 & -181.63 \\
$\mathrm{BSSE}$ & 7.25 & 7.93 & 5.35 & 5.83 & 7.58 & 3.85 & 6.06 \\
\hline & $2.74,2.68$, & $2.84,2.76$, & $2.71,2.70$, & $2.58,2.77$, & $2.87,2.93$, & $4.16,4.28$, & $6.14,5.79$, \\
$\mathrm{R}\left(\mathrm{K}^{+}-\mathrm{X}\right)$, & $2.68,2.72$, & $2.84,2.76$, & $3.88,4.05$, & $3.88,2.88$, & $2.83,2.84$, & $6.42,6.47$, & $2.95,2.82$, \\
$\mathrm{X}=\mathrm{O}, \mathrm{N}$ & $5.40,4.48$, & $3.00,3.00$, & $5.83,6.81$, & $6.85,6.05$, & $2.96,2.73$, & $4.09,7.43$, & $2.75,4.38$, \\
& $3.34,2.95$ & $2.85,2.85$ & $4.84,4.98$ & $4.50,4.90$ & $2.92,2.92$ & $6.12,4.69$ & $4.27,5.00$ \\
\hline
\end{tabular}

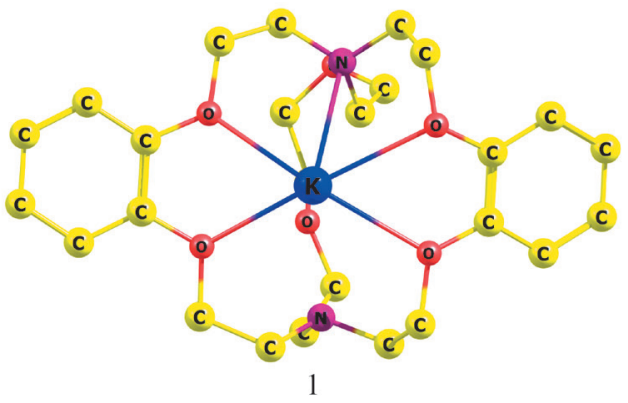

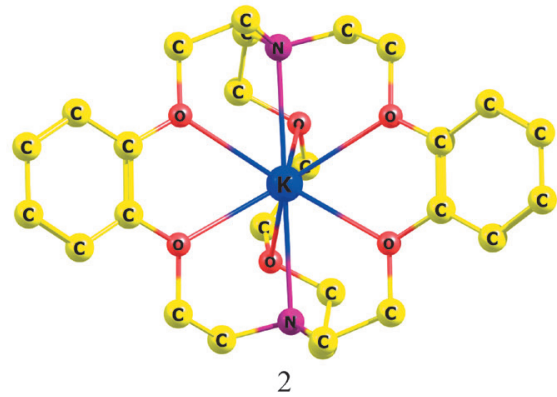

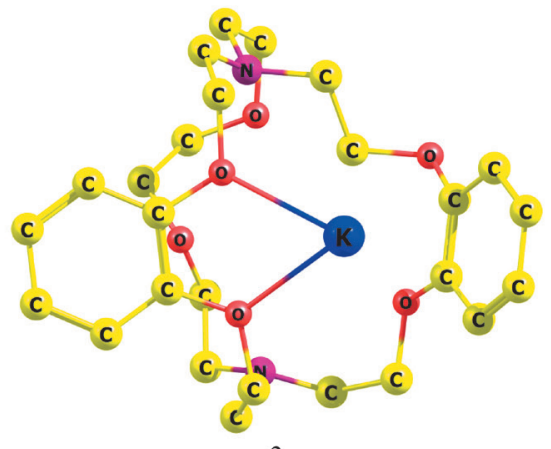

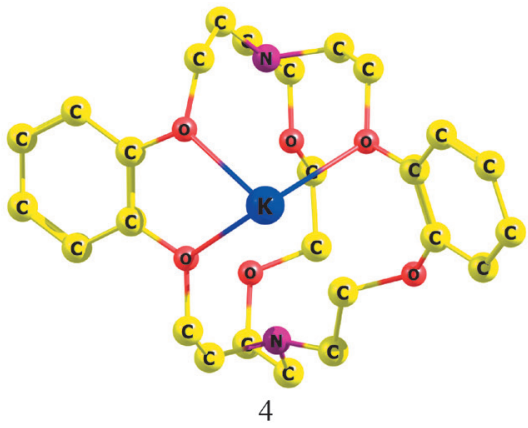

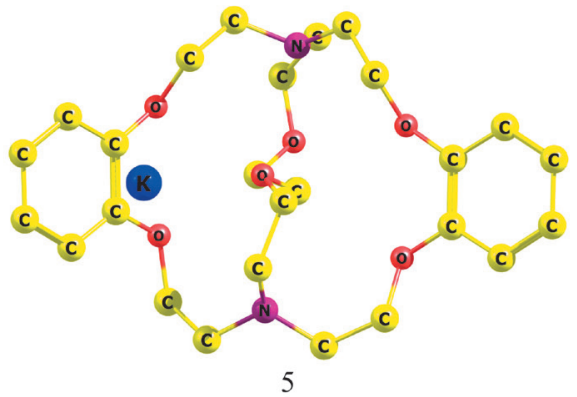

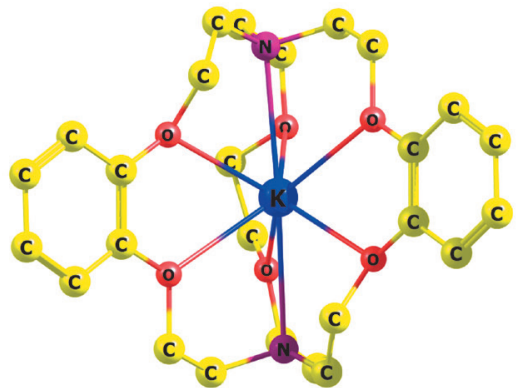

$4-1$

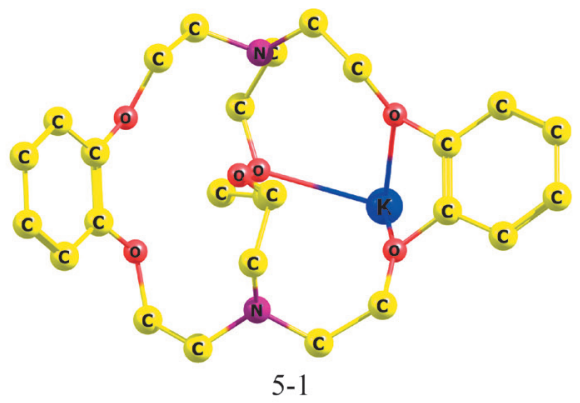

Figure 2. Structures of K 2.2.2BB- $\mathrm{K}^{+}$complexes (hydrogen atoms are not shown). 
Table 3. Stabilization energy of coordination bonds in complexes $(\Delta E)$. Difference of stabilization energy in vacuum and in DMSO $(\Delta \Delta E)$ for two conformations.

\begin{tabular}{|c|c|c|}
\hline & $\Delta E, \mathrm{kcal}$ & $\Delta \Delta E$ \\
\hline \multicolumn{3}{|c|}{ 1_K } \\
\hline$\Sigma \mathrm{LP}(1,2) \mathrm{O} 2->\mathrm{LP} *(1-4) \mathrm{K}$ & 13.77 & 0.46 \\
\hline$\Sigma \mathrm{LP}(1,2) \mathrm{O} 3->\mathrm{LP} *(1-4) \mathrm{K}$ & 14.11 & 0.49 \\
\hline$\Sigma \mathrm{LP}(1) \mathrm{N} 12->\mathrm{LP} *(1,2) \mathrm{K}$ & 7.08 & -0.03 \\
\hline$\Sigma \mathrm{LP}(1) \mathrm{N} 15->\mathrm{LP} *(1,2) \mathrm{K}$ & 7.09 & -0.02 \\
\hline$\Sigma \mathrm{LP}(1,2) \mathrm{O} 26->\mathrm{LP} *(1-4) \mathrm{K}$ & 14.08 & 0.46 \\
\hline$\Sigma \mathrm{LP}(1,2) \mathrm{O} 29->\mathrm{LP} *(1-4) \mathrm{K}$ & 12.26 & -1.05 \\
\hline$\Sigma \mathrm{LP}(1,2) \mathrm{O} 38->\mathrm{LP} *(1-4) \mathrm{K}$ & 12.88 & 0.11 \\
\hline$\Sigma \mathrm{LP}(1,2) \mathrm{O} 45->\mathrm{LP} *(1-4) \mathrm{K}$ & 12.89 & 0.12 \\
\hline$\Sigma \mathrm{LP}(1,2) \mathrm{O} 2->\mathrm{LP} *(1-4) \mathrm{K}$ & 13.77 & 0.46 \\
\hline$\Sigma \mathrm{LP}(1,2) \mathrm{O} 3->\mathrm{LP} *(1-4) \mathrm{K}$ & 14.11 & 0.49 \\
\hline$\Sigma \mathrm{LP}(1) \mathrm{N} 12->\mathrm{LP} *(1,2) \mathrm{K}$ & 7.08 & -0.03 \\
\hline$\Sigma \mathrm{LP}(1) \mathrm{N} 15->\mathrm{LP} *(1,2) \mathrm{K}$ & 7.09 & -0.02 \\
\hline$\Sigma \mathrm{LP}(1,2) \mathrm{O} 26->\mathrm{LP} *(1-4) \mathrm{K}$ & 14.08 & 0.46 \\
\hline$\Sigma \mathrm{LP}(1,2) \mathrm{O} 29->\mathrm{LP} *(1-4) \mathrm{K}$ & 12.26 & -1.05 \\
\hline \multicolumn{3}{|c|}{$2 K$} \\
\hline$\Sigma \mathrm{LP}(1,2) \mathrm{O} 2->\mathrm{LP} *(1-4) \mathrm{K}$ & 13.77 & 0.46 \\
\hline$\Sigma \mathrm{LP}(1,2) \mathrm{O} 3->\mathrm{LP} *(1-4) \mathrm{K}$ & 14.11 & 0.49 \\
\hline$\Sigma \mathrm{LP}(1) \mathrm{N} 12->\mathrm{LP} *(1,2) \mathrm{K}$ & 7.08 & -0.03 \\
\hline$\Sigma \mathrm{LP}(1) \mathrm{N} 15->\mathrm{LP} *(1,2) \mathrm{K}$ & 7.09 & -0.02 \\
\hline$\Sigma \mathrm{LP}(1,2) \mathrm{O} 26->\mathrm{LP}^{*}(1-4) \mathrm{K}$ & 14.08 & 0.46 \\
\hline$\Sigma \mathrm{LP}(1,2) \mathrm{O} 29->\mathrm{LP} *(1-4) \mathrm{K}$ & 12.26 & -1.05 \\
\hline$\Sigma \mathrm{LP}(1,2) \mathrm{O} 38->\mathrm{LP} *(1-4) \mathrm{K}$ & 12.88 & 0.11 \\
\hline$\Sigma \mathrm{LP}(1,2) \mathrm{O} 45->\mathrm{LP} *(1-4) \mathrm{K}$ & 12.89 & 0.12 \\
\hline \multicolumn{3}{|l|}{ 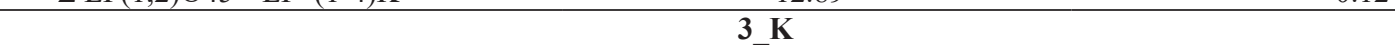 } \\
\hline$\Sigma \mathrm{LP}(1,2) \mathrm{O} 2->\mathrm{LP} *(1-4,7) \mathrm{K}$ & 6.15 & \\
\hline$\Sigma \mathrm{LP}(1,2) \mathrm{O} 3->\mathrm{LP} *(1-4,6) \mathrm{K}$ & 6.39 & \\
\hline$\Sigma \mathrm{LP}(1) \mathrm{N} 12->\mathrm{LP} *(1,3,4) \mathrm{K}$ & 1.10 & \\
\hline LP(1)N15->LP*(1)K & 0.36 & \\
\hline$\Sigma \mathrm{LP}(1,2) \mathrm{O} 26->\mathrm{LP} *(1-4) \mathrm{K}$ & 0.90 & \\
\hline$\Sigma \mathrm{LP}(1,2) \mathrm{O} 29->\mathrm{LP} *(1-4) \mathrm{K}$ & 1.30 & \\
\hline LP(1)O45->LP*(1)K & 0.40 & \\
\hline \multicolumn{3}{|c|}{ 4_K } \\
\hline$\Sigma \mathrm{LP}(1,2) \mathrm{O} 2->\mathrm{LP} *(1-4,6) \mathrm{K}$ & 6.18 & \\
\hline$\Sigma \mathrm{LP}(1,2) \mathrm{O} 3->\mathrm{LP} *(1,3,4) \mathrm{K}$ & 5.25 & \\
\hline LP(1)N12->LP*(1)K & 0.35 & \\
\hline$\Sigma \mathrm{LP}(1) \mathrm{N} 15->\mathrm{LP} *(1,2,4) \mathrm{K}$ & 1.80 & \\
\hline$\Sigma \mathrm{LP}(1,2) \mathrm{O} 26->\mathrm{LP} *(1-5) \mathrm{K}$ & 5.70 & \\
\hline$\Sigma \mathrm{LP}(1,2) \mathrm{O} 29->\mathrm{LP} *(1,2,7) \mathrm{K}$ & 1.30 & \\
\hline$\Sigma \mathrm{BD}(1,2) \mathrm{C}_{\mathrm{N} 1}-\mathrm{C}_{\mathrm{N} 2}->\mathrm{LP} *(1-5,7,8) \mathrm{K}$ & 11.12 & \\
\hline \multicolumn{3}{|l|}{ 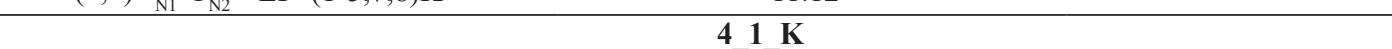 } \\
\hline$\Sigma \mathrm{LP}(1,2) \mathrm{O} 2->\mathrm{LP}^{*}(1-4) \mathrm{K}$ & 14.12 & \\
\hline$\Sigma \mathrm{LP}(1,2) \mathrm{O} 3->\mathrm{LP} *(1-4) \mathrm{K}$ & 12.62 & \\
\hline$\Sigma \mathrm{LP}(1) \mathrm{N} 12->\mathrm{LP} *(1,2) \mathrm{K}$ & 7.00 & \\
\hline$\Sigma \mathrm{LP}(1) \mathrm{N} 15->\mathrm{LP} *(1-3) \mathrm{K}$ & 6.65 & \\
\hline$\Sigma \mathrm{LP}(1,2) \mathrm{O} 26->\mathrm{LP} *(1-4) \mathrm{K}$ & 12.66 & \\
\hline$\Sigma \mathrm{LP}(1,2) \mathrm{O} 29->\mathrm{LP}^{*}(1-4) \mathrm{K}$ & 14.25 & \\
\hline$\Sigma \mathrm{LP}(1,2) \mathrm{O} 38->\mathrm{LP} *(1-4) \mathrm{K}$ & 14.42 & \\
\hline$\Sigma \mathrm{LP}(1,2) \mathrm{O} 45->\mathrm{LP} *(1-4) \mathrm{K}$ & 13.16 & \\
\hline \multicolumn{3}{|c|}{ 5_K } \\
\hline LP(1)N12->LP*(1)K & 0.08 & \\
\hline$\Sigma \mathrm{LP}(1,2) \mathrm{O} 26->\mathrm{LP} *(1,2,4) \mathrm{K}$ & 0.47 & \\
\hline$\Sigma \mathrm{LP}(1) \mathrm{O} 29->\mathrm{LP} *(1,4) \mathrm{K}$ & 0.29 & \\
\hline$\Sigma \mathrm{LP}(1) \mathrm{O} 45->\mathrm{LP} *(1,4) \mathrm{K}$ & 1.09 & \\
\hline$\Sigma \mathrm{BD}(1) \mathrm{C}_{\mathrm{N} 1}-\mathrm{C}_{\mathrm{N} 2}->\mathrm{LP} *(1,2) \mathrm{K}$ & 4.88 & \\
\hline \multicolumn{3}{|c|}{ 5_1_K } \\
\hline$\Sigma \mathrm{LP}(1,2) \mathrm{O} 2->\mathrm{LP} *(1,3,4) \mathrm{K}$ & 4.20 & \\
\hline$\Sigma \mathrm{LP}(1,2) \mathrm{O} 3->\mathrm{LP} *(1-3) \mathrm{K}$ & 5.25 & \\
\hline LP(1)N12->LP*(1)K & 0.08 & \\
\hline$\Sigma \mathrm{LP}(1) \mathrm{N} 15->\mathrm{LP} *(1,2) \mathrm{K}$ & 0.38 & \\
\hline $\mathrm{LP}(1) \mathrm{O} 26->\mathrm{LP} *(1) \mathrm{K}$ & 0.05 & \\
\hline LP(1)O29->LP*(1)K & 0.11 & \\
\hline$\Sigma \mathrm{LP}(1,2) \mathrm{O} 38->\mathrm{LP} *(1-3) \mathrm{K}$ & 4.43 & \\
\hline$\Sigma \mathrm{LP}(1) \mathrm{O} 45->\mathrm{LP} *(1,5) \mathrm{K}$ & 0.69 & \\
\hline$\Sigma \mathrm{BD}(1) \mathrm{C}_{\mathrm{N} 1}-\mathrm{C}_{\mathrm{N} 2}->\mathrm{LP} *(1,2) \mathrm{K}$ & 4.34 & \\
\hline
\end{tabular}


of coordination bonds of all the studied complexes are shown in Table 3. As the table shows, the cryptand complexes with potassium form as a result of competition between interactions of potassium with oxygen and nitrogen atoms, on the one hand, and potassium with $\pi$-systems of benzene rings, on the other hand. The interaction of potassium with $\pi$-systems is strong enough $(\sim 10-14 \mathrm{kcal} / \mathrm{mol})$ to shift the potassium from the cavity center to its periphery and, hence, to decrease the interaction energies and to increase the distances from some cryptand oxygen and nitrogen atoms (Tables 2,3). On the other hand, the conformation of cryptand changes noticeably (Figure 2). In configurations with the maximum binding energy ( $\mathrm{K}$ 2.2.2BB_1_K, $\mathrm{K}$ 2.2.2BB_4_1_K), the interaction energy with the $\pi$-systems is close to zero (Table 3 ).

Therefore, the existence of benzene rings in $\mathrm{K} 2.2 .2 \mathrm{BB}$ cryptand leads to formation of stable structures, where the cation shifts to the cavity periphery as a result of structural changes in the ligand. This feature distinguishes cryptand $\mathrm{K}$ 2.2.2BB from cryptand $\mathrm{K} 2.2 .2$ where such configurations are not stable. ${ }^{[6]}$ On the other hand, it can be assumed that cryptand solvation significantly affects the thermodynamics of complex formation. To study this phenomenon we made quantum-chemical calculations of $\mathrm{K} 2.2 .2 \mathrm{BB} 1 \mathrm{~K}$ and $\mathrm{K}$ 2.2.2BB_2_K complexes with the solvent in CPCM approximation. The CPCM model parameters corresponded to those of dimethyl sulfoxide. The thermodynamic parameters of complex formation are shown in Table 4.

Table 4. Energy of complex formation of $\mathrm{K}$ 2.2.2BB conformers with $\mathrm{K}^{+}$in DMSO in CPCM approximation.

\begin{tabular}{ccc}
\hline & $\mathbf{1}$ & $\mathbf{2}$ \\
\hline$\Delta E^{0}, \mathrm{~kJ} / \mathrm{mol}$ & -1.79 & -53.27 \\
$\Delta G, \mathrm{~kJ} / \mathrm{mol}$ & 26.90 & -16.79 \\
\hline
\end{tabular}

Cryptand solvation by a polar solvent leads to a considerable reduction in the free energy of complex formation. As the calculations have shown, an increase in the dielectric constant of the solvent from 7.4 (tetrahydrofuran) to 37.2 ( $N, N$-dimethylformamide) and 46.8 (dimethylsulfoxide), the free energy of complex formation $(\Delta G)$ decreases in the following order: $-47.9,-18.3,-16.8 \mathrm{~kJ} / \mathrm{mol} .{ }^{[15]}$ Among all the considered configurations, there is only one stable configuration corresponding to the complex with the minimal free energy in vacuum (Table 4). The NBO analysis results clearly demonstrate selectivity of the solvent effect. Namely, the solvation of solvent molecules has virtually no effect on the stabilization of coordination bond energy in the complex with a cation located in the cavity center (2nd conformation, Table 3). However, the situation drastically changes for the complex where the cation is shifted to the periphery due to the interaction with the $\pi$-systems of benzene rings, (first conformation, Table 3). Stabilization energies of coordination bonds in the solvent decrease essentially, which eventually leads to thermodynamic instability of these configurations.

\section{References}

1. Lewis D.Y., Solovyov D., Brindle K.M. Cancer J. 2015, 21, 129-36.

2. PET and SPECT in Psychiatry (Dierckx R.A.J.O., Otte A., de Vries E.F.J., van Waarde A., Eds.), Springer-Verlag, BerlinHeidelberg, 2014. 849 p.

3. Gulyás B., Halldin C. Q. J. Nucl. Med. Mol. Im. 2012, 56, 173190.

4. Hamacher K., Coenen H.H., Stocklin G. Nucl. Med. Biol. 1986, 27, 235-238.

5. Richter S., Wuest F. Molecules 2014, 19, 20536-20556.

6. Su J.W., Burnette R.R. ChemPhysChem 2008, 9, 1989-1996.

7. Leite E.S., Santana S.R., Hunenberger P.H., Freitas L.C.G., Longo R.L. J. Mol. Model. 2007, 13, 1017-1025.

8. Wang X., Wang H., Tan Y. J. Comput. Chem. 2008, 29, 14231428.

9. Begel S., Puchta R., van Eldik R. Beilstein J. Org. Chem. 2013, 9, 1252-1268.

10. US Patent 5,264,70: Nov. 23, 1993.

11. Cox B.G., Firman P., Schneider I., Schneider H. Inorg. Chim. Acta 1981, 49, 153.

12. Buschmann H.-J., Cleve E., Denter U., Schollmeyer E. J. Phys. Org. Chem. 1994, 7, 479-484.

13. Gaussian 09, Revision E.01. Frisch M.J., Trucks G.W., Schlegel H.B., et al. Gaussian, Inc., Wallingford CT, 2009.

14. Foster J.P., Weinhold F. J. Am. Chem. Soc. 1980, 102, 72117218.

15. Landolt-Börnstein - Group IV Physical Chemistry, Vol. 17, Supplement to IV/6 (Lechner M.D., Ed.) Springer, 2008. 154 p. 